\title{
Correspondence
}

https://doi.org/10.11646/zootaxa.5093.3.8

http://zoobank.org/urn:lsid:zoobank.org:pub:AB55E9E9-602B-4FD8-8B37-6C7F5B857322

\section{Description of a second species of the eulimid genus Concavibalcis (Gastropoda: Vanikoroidea)}

\author{
TSUYOSHI TAKANO ${ }^{1}$, SHOUJI TSUZUKI $^{2} \&$ YASUNORI KANO $^{3}$ \\ ${ }^{1}$ Meguro Parasitological Museum, 4-1-1 Shimomeguro, Meguro, Tokyo 153-0064, Japan. \\ "=ttakano@kiseichu.org; (1) https://orcid.org/0000-0002-1033-3445 \\ 253-17 Oyumi, Chiba, Chiba 260-0813, Japan. ఏ"urumashell9860@gmail.com \\ ${ }^{3}$ Atmosphere and Ocean Research Institute, The University of Tokyo, 5-1-5 Kashiwanoha, Kashiwa, Chiba 277-8564, Japan. \\ ="kano@aori.u-tokyo.ac.jp; @ https://orcid.org/0000-0002-9527-5116
}

Snails of the family Eulimidae (subclass Caenogastropoda) are parasitic to the Echinodermata of all five classes, namely Asteroidea, Crinoidea, Echinoidea, Holothuroidea and Ophiuroidea (Warén 1983a; Takano \& Kano 2014). The Eulimidae exhibit a large variety of parasitic modes, sexual strategies and shell shapes (Warén 1983a), making them an unrivaled lineage to investigate evolutionary aspects of parasitism in gastropods. Numerous taxa, however, still remain to be described and to be examined for their parasitic ecology.

Concavibalcis Warén, 1980 is one of the least known genera of Eulimidae. The type and only known species $C$. scalaris Warén, 1980 was described from 365-400 m deep off Luzon Island, the Philippines, based on ten empty shells and one live-collected specimen with a rotten soft part inside (Warén 1980b). This rotten soft part exhibited the presence of pigmented eyes and probable lack of the radula (Warén 1980b). However, the absence of additional specimens or species since then has resulted in a near-total lack of knowledge on the ecology, anatomy, and phylogenetic position of Concavibalcis.

One of the present authors (S.T.) recently collected twenty-four empty shells of a eulimid species from shallow subtidal sediment off Hateruma Island, Okinawa, Japan. We herein describe them as a second species of the genus, Concavibalcis haterumaensis n. sp. The shells were dried and measured for height and diameter (SH, SD); two were mounted on a stub and coated with platinum for SEM observation (Hitachi S-4800) at the Atmosphere and Ocean Research Institute, The University of Tokyo. Study specimens have been deposited in the National Museum of Nature and Science, Tokyo (NSMT) and Meguro Parasitological Museum (MPM).

\section{Taxonomy}

\section{Superfamily Vanikoroidea Gray, 1840}

Family Eulimidae Philippi, 1853

Genus Concavibalcis Warén, 1980

Type species. Concavibalcis scalaris Warén, 1980, by original designation.

Remarks. The holotype of C. scalaris (Smithsonian National Museum of Natural History, USNM 277426) was collected from 390 m off Motocot Point, Luzon Island, the Philippines (Warén 1980b: 294). Its shell is characterized by (1) a height of $5.1 \mathrm{~mm}$, (2) a conical outline, (3) a slightly chalky appearance, (4) a blunt apex without clear demarcation between the protoconch and teleoconch, (5) shouldered, distinctly concave teleoconch whorls, (6) an ovate aperture, and (7) a strongly curved outer lip (Warén 1980b: figs. 32-34, 1983a).

Warén (1980b) noted some resemblance between C. scalaris and certain species of Zebina H. Adams \& A. Adams, 1854 (Caenogastropoda: Rissooidea: Zebinidae) in teleoconch morphology. The latter genus is, however, characterized by an aperture with a more developed basal notch and a straight, opisthocline outer lip (Warén 1980b; Ponder 1985). Concavibalcis scalaris is also similar to Turriodostomia nakayamai (Habe, 1961) (Heterobranchia: Pyramidelloidea: Pyramidellidae) in sharing shouldered, concave teleoconch whorls, whereas only the latter species has a strong columellar fold in the aperture (Habe 1961). The familial assignment of $C$. scalaris to Eulimidae is justified by the simple shell aperture without a basal notch or a columellar fold and by a probable lack of a radula (Warén 1980b). The presence of incremental scars in the present new species (see below) further corroborates the eulimid affinity of Concavibalcis. 


\section{Concavibalcis haterumaensis n. sp.}

(Fig. 1)

Type locality. Nishi-hama, Hateruma Island, Taketomi, Okinawa, Japan $\left(24^{\circ} 04^{\prime} 06^{\prime \prime} \mathrm{N}, 123^{\circ} 45^{\prime} 46^{\prime \prime} \mathrm{E}\right)$, sandy bottom at a depth of $4 \mathrm{~m}$.

Type material. Holotype NSMT-Mo 79320; 8 paratypes NSMT-Mo 79321; 3 paratypes MPM Coll. No. 21794a-c, all collected from the type locality on May 30, 2019. 2 paratypes (MPM Coll. No. 21794a, b) coated with platinum for SEM observation.

Other material examined. 12 specimens MPM Coll. No. 21795, collected together with the type specimens.

Etymology. The name refers to the type locality, Hateruma Island.

Distribution. Known only from the type locality.

Diagnosis. Species of Concavibalcis with a small, thick, white translucent shell, lacking chalky appearance. Teleoconch surface decorated with very fine spiral ridges. Aperture ovate, callused; outer lip simple, curved, constricted below suture, with most protruding part at half of aperture height in lateral view.

Description. Shell conical with blunt apex, up to $3.1 \mathrm{~mm}$ high, thick, solid, white translucent (Fig. 1A, B). Protoconch dome-shaped, smooth, glassy translucent white, with 1.3 whorls; demarcation line with teleoconch faint, straight, opisthocline; exposed part $220 \mu \mathrm{m}$ wide and $250 \mu \mathrm{m}$ high (Fig. 1C). Up to 6.4 teleconch whorls, concave near shoulder and convex below; suture well defined and encircled by a rounded keel (Fig. 1B); incremental scars distinct (Fig. 1D), situated at 0.7, 1.6, 2.0, 2.7, 3.4, 4.1, 4.5, 5.0 and 5.5 whorls from aperture in holotype. First two to three teleoconch whorls bear short, oblique, slightly curved ridges on upper two-thirds and continuous spiral ridges on lower one-third of each whorl (Fig. 1E). Later whorls bear spirals only, which are stronger and more widely spaced towards suture of next whorl (Fig. 1D). Last adult whorl occupies $55 \%$ of total shell height. Aperture ovate; outer lip simple, curved, retracted near suture, sigmoid with most protruding part at half of aperture height in lateral view; parietal wall and columellar lip joining in a slight arc; columellar and parietal callus well developed; basal lip rounded.

Dimensions. Holotype: $3.0 \mathrm{~mm}$ in SH and $1.2 \mathrm{~mm}$ in SD; 11 paratypes: $2.0-3.1 \mathrm{~mm}$ in SH and $0.8-1.2 \mathrm{~mm}$ in SD.

Remarks. The assignment of the present new species to Concavibalcis is supported by its shouldered, concave teleoconch whorls, and its blunt apex with a dome-shaped paucispiral protoconch (Fig. 1; Warén 1980b). The former condition is rare among the Eulimidae and found in only a few other genera, including Oceanida de Folin, 1870 and Scalaribalcis Warén, 1980. However, Oceanida differs in having a taller, pupiform protoconch, and Scalaribalcis in having an ovate outline of the teleoconch with a much broader aperture (Warén 1983a). The shell apex is blunt in such genera as Fusceulima Laseron, 1955, Halielloides Bouchet \& Warén, 1986 and Teretianax Iredale, 1918, but their teleoconch features differ greatly from those of the present species and of C. scalaris, the type and only known species of Concavibalcis (Warén 1983b; Souza \& Pimenta 2014; Hori \& Matsuda 2017).

Concavibalcis haterumaensis $\mathbf{n}$. sp. is distinguished from C. scalaris in having (1) a smaller, thicker shell and (2) fine spiral ridges on teleoconch whorls. The two species have nearly the same number of teleoconch whorls (up to 6.4 and 6.5 , respectively), meaning that $C$. haterumaensis $\mathbf{n} . \mathbf{s p}$. $(3.1 \mathrm{~mm}$ high) is more tightly coiled with a lower expansion rate of the aperture than C. scalaris (5.1 mm high). The presence or absence of fine spirals is a species-specific character also in other eulimid genera (e.g. Annulobalcis Habe, 1965, Melanella Bowdich, 1822 and Trochostilifer Warén, 1980; Warén 1980b; Gofas et al. 2011; Dgebuadze et al. 2012). Furthermore, (3) the polished translucent shell of the new species differs from the chalky shell of the type species, although the latter chalky appearance may be attributable to corrosion in the specimens examined (see Warén 1980b). Their habitats also differ from each other: (4) C. haterumaensis $\mathbf{n}$. sp. was collected from a shallow subtidal site, whereas C. scalaris lives in deeper, bathyal waters (365-400 m; Warén 1980b). Several eulimid genera exhibit a similar broad bathymetric range (e.g. Melanella, Pelseneeria Koehler \& Vaney, 1908, Stilapex Iredale, 1925 and Thyca H. Adams \& A. Adams, 1854; Warén 1980a, 1981, 1983a; Hori \& Matsuda 2017; T. Takano personal observation).

The genus Concavibalcis remains to be the least studied among the Eulimidae from phylogenetic and ecological perspectives. Eulimid species in closely related genera exploit hosts of the same echinoderm class (Warén 1983a; Takano \& Goto 2021). Future phylogenetic reconstruction for Concavibalcis based on live-taken specimens may lead to a better understanding of its parasitic ecology and vice versa. 


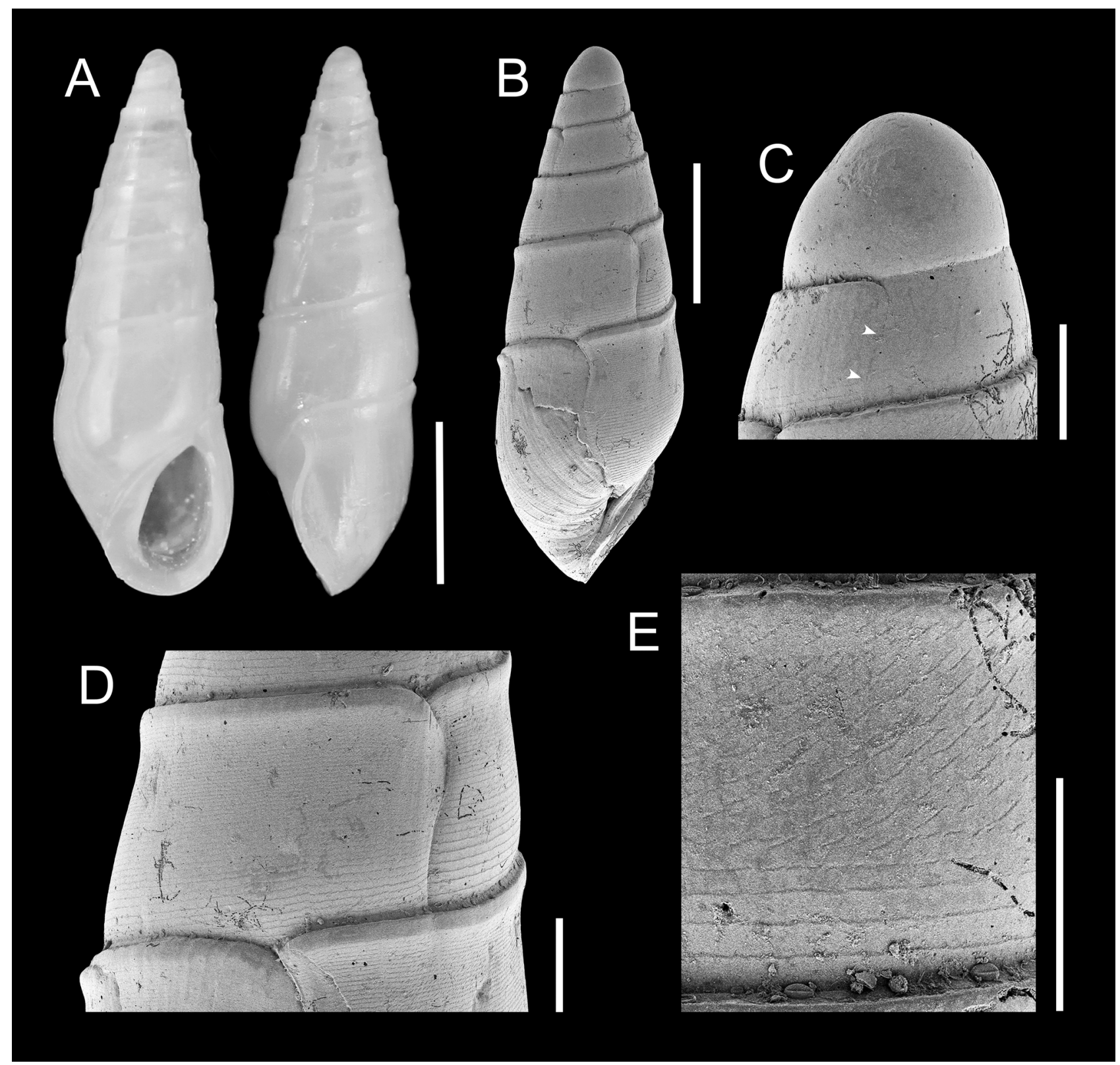

FIGURE 1. Concavibalcis haterumaensis n. sp. A. Holotype NSMT-Mo 79320, $3.0 \mathrm{~mm}$ in shell height. B-E. Paratype MPM Coll. No. 21794a, 2.0 mm, SEM. B. Lateral view showing incremental scars in penultimate and last whorls. C. Close-up view of blunt apex; arrowheads denote demarcation line between protoconch and teleoconch. D. Penultimate whorl with an incremental line and fine spiral ridges. E. Surface of first teleoconch whorl showing short oblique ridges and continuous spiral ridges. Scale bars $=1 \mathrm{~mm}(\mathrm{~A}), 500 \mu \mathrm{m}(\mathrm{B})$ and $100 \mu \mathrm{m}(\mathrm{C}-\mathrm{E})$.

\section{Acknowledgements}

Invaluable comments were provided by three anonymous reviewers for the improvement of the manuscript.

\section{References}

Dgebuadze, P.Y., Fedosov, A.E. \& Kantor, Y.I. (2012) Host specificity of parasitic gastropods of the genus Annulobalcis Habe, 1965 (Mollusca, Gastropoda, Eulimidae) from crinoids in Vietnam, with descriptions of four new species. Zoosystema, 34, $139-155$.

https://doi.org/10. 5252/z2012n1a6

Gofas, S., Moreno, D. \& Salas, C. (2011) Moluscos marinos de Andalucía, vol. I. Servicio de Publicaciones e Intercambio Cientifico. Universidad de Málaga, Málaga, 342 pp. 
Habe, T. (1961) Description of fifteen new species of Japanese shells. Venus, 21, 416-431. https://doi.org/10.18941/venusjjma.21.4_416

Hori, S. \& Matsuda, H. (2017) Family Eulimidae. In: Okutani, T. (Ed.), Marine Mollusks in Japan, the Second Edition. Tokai University Press, Hiratsuka, pp. 142-151, 823-832.

Ponder, W.F. (1985) A review of the genera of the Rissoidae (Mollusca: Mesogastropoda: Rissoacea). Records of the Australian Museum, Supplement 4, 1-221.

https://doi.org/10.3853/j.0812-7387.4.1985.100

Souza, L.S. \& Pimenta, A.D. (2014) Fusceulima and Halielloides (Gastropoda: Eulimidae) in the southwestern Atlantic, with descriptions of two new species of Fusceulima. Zoologia, 31, 621-633. https://doi.org/10.1590/S1984-46702014000600008

Takano, T. \& Kano, Y. (2014) Molecular phylogenetic investigations of the relationships of the echinoderm-parasite family Eulimidae within Hypsogastropoda (Mollusca). Molecular Phylogenetics and Evolution, 79, 258-269. https://doi.org/10.1016/j.ympev.2014.06.021

Takano, T. \& Goto, R. (2021) Molecular and morphological systematics of the crinoid-parasitic snail genus Goodingia (Mollusca: Caenogastropoda: Eulimidae) with new insights into intrafamilial phylogenetic relationships. Marine Biodiversity, $51,5$. https://doi.org/10.1007/s12526-020-01141-0

Warén, A. (1980a) Revision of the genera Thyca, Stilifer, Scalenostoma, Mucronalia and Echineulima (Mollusca, Prosobranchia, Eulimidae). Zoologica Scripta, 9, 187-210. https://doi.org/10.1111/j.1463-6409.1980.tb00663.x

Warén, A. (1980b) Descriptions of new taxa of Eulimidae (Mollusca, Prosobranchia), with notes on some previously described genera. Zoologica Scripta, 9, 283-306. https://doi.org/10.1111/j.1463-6409.1980.tb00668.x

Warén, A. (1981) Revision of the genera Apicalia A. Adams and Stilapex Iredale and description of two new genera (Mollusca, Prosobranchia, Eulimidae). Zoologica Scripta, 10, 133-154. https://doi.org/10.1111/j.1463-6409.1981.tb00491.x

Warén, A. (1983a) A generic revision of the family Eulimidae (Gastropoda, Prosobranchia). Journal of Molluscan Studies, Supplement 13, 1-96. https://doi.org/10.1093/mollus/49.Supplement_13.1

Warén, A. (1983b) An anatomical description of Eulima bilineata Alder with remarks on and a revision of Pyramidelloides Nevill (Mollusca, Prosobranchia, Eulimidae). Zoologica Scripta, 12, 273-294.

https://doi.org/10.1111/j.1463-6409.1983.tb00511.x 